\title{
Optimization of RAPD-PCR Conditions for the Study of Genetic Diversity of Centella asiatica
}

\author{
Anjana Devkota ${ }^{1}$, Hari P. Bimb ${ }^{2}$, Jwala Bajracharya ${ }^{2}$ and Pramod K. Jha ${ }^{1}$ \\ ${ }^{1}$ Central Department of Botany, Tribhuvan University, Kirtipur, Kathmandu \\ ${ }^{2}$ Nepal Agriculture Research Council (NARC), Khumaltar, Lalitpur \\ e-mail:devkotaa@gmail.com
}

\begin{abstract}
Random amplified polymorphic DNA (RAPD) is one of the molecular marker tools available for detecting the polymorphism in plant species. It has been used extensively for genetic diversity studies. In the present investigation, the RAPD reaction and cycling conditions were optimized for generating RAPD fingerprints of twenty one ecotypes of Centella. asiatica (L.) urban collected from different locations of Nepal. To determine the optimum conditions for PCR amplification, different concentrations of master mix ( $2 \mathrm{X}$ mix , Promega USA), template DNA, primer and PCR cycling conditions were varied. Reproducible amplified products were observed using $0.5 \mu \mathrm{M}$ of primer, $12.5 \mu \mathrm{l}$ master mix (2X), and 100 ng of template DNA in $25 \mu \mathrm{l}$ reaction volume of PCR. Cycling conditions were optimized with varying annealing temperature and initial denaturation temperature. The best cycling condition comprised of an initial denaturation of $3 \mathrm{~min}$ at $94^{\circ} \mathrm{C}$, followed by 30 cycles of denaturation for $45 \mathrm{sec}$ at $94^{\circ} \mathrm{C}$, annealing for $1 \mathrm{~min}$ at $37^{\circ} \mathrm{C}$, and extension for $1 \mathrm{~min}$ at $72^{\circ} \mathrm{C}$ and final extension at $72^{\circ} \mathrm{C}$ for $7 \mathrm{~min}$. Of the 21 random primers tested, only 8 primers produced the best and reproducible amplification products. The optimized RAPD-PCR conditions and selected primers were subsequently used for the study of genetic diversity in C. asiatica.
\end{abstract}

Key words: Centella asiatica, primer, master mix, DNA template, optimization, RAPD-PCR conditions

\section{Introduction}

Centella asiatica (L.) Urban (Apiaceae) commonly called Indian pennywort or brahmi is a perennial creeping herb, commonly found growing in moist places. The plant is distributed throughout Nepal up to $2200 \mathrm{~m}$ asl (Press et al. 2000). It is used as an alternative medicine for tonic, leprosy, blood purifier, diuretic and for indigestion (Shrestha \& Dhillion 2003, Sajem \& Gosai 2006). Fresh leaves are taken for improving the memory power, as well as used as a tonic and curing the skin diseases, and also as a medicine for syphilis and rheumatism (Sajem \& Gosai 2006).

C. asiatica contains a variety of useful compounds, mainly of triterpenoids, flavonoids, alkaloids, polysaccharides, steroids and essential oils (Jamil et al. 2007). However, the occurrence of high amounts of 
polysaccharides, polyphenols, tannins, hydrocolloids (sugars and carragenans) and other secondary metabolites: alkaloids, flavanoids phenols, terpenes and quinines interfere the process of DNA isolation. The problems encountered in the isolation and purification of DNA specially from medicinal plant (C. asiatica) include the degradation of DNA due to terpenoids, coisolation of highly viscous polysaccharides, and other secondary metabolites which directly or indirectly interfere with the enzymatic reactions (Padmalatha and Prasad, 2006). Moreover, the contaminating RNA that precipitates along with DNA causes problems suppressing PCR amplification (Pikkart \& Villeponteau 1993), and improper priming of DNA templates during thermal cycle sequencing.

Optimization of RAPD-PCR Conditions is essential for genetic diversity study .It helps to find out the optimimum PCR condition and cycling parameter. Optimization of PCR condition is necessary as it shortens the research duration and economize the reagent cost of PCR. In this paper, we report total genomic DNA isolation protocol for C. asiatica which is slightly modified version of the method originally developed for other plants (Doyle \& Doyle 1987), together with optimization of PCR and other cycling conditions that may help to economise quantity of DNA , primer and usage of PCR mixes (2X).

\section{Methodology}

Materials: Twenty one populations of C. asiatica collected from different districts of Nepal were used in the study (Table 1). Herbaria of collected specimens were prepared according to standard methods.

Table 1. Distribution and physiographical parameters of C. asiatica at various locations in Nepal.

\begin{tabular}{|c|c|c|c|c|c|}
\hline SN & Districts & Accessions & Altitude (m) & Longitude & Latitude \\
\hline 1 & Gorkha & CAGor & 600 & $84^{\circ} 38.74^{\prime} \mathrm{E}$ & $28^{\circ} 01.39^{\prime \prime N}$ \\
\hline 2. & Jhapa & CAJha & 96 & $88^{\circ} 3.05^{\prime} \mathrm{E}$ & $26^{\circ} 31.6^{\prime} \mathrm{N}$ \\
\hline 3 & Sunsari & CASun & 85 & $87^{\circ} 1.61 ' \mathrm{E}$ & $26^{\circ} 41.28^{\prime} \mathrm{N}$ \\
\hline 4 & Daman & CADam & 2350 & $85^{\circ} 0.05^{\prime} \mathrm{E}$ & $27^{\circ} 35^{\prime} \mathrm{N}$ \\
\hline 5 & Lalitpur & CALal & 1600 & $85^{\circ} 22.70^{\prime} \mathrm{E}$ & $27^{\circ} 35.72 \mathrm{~N}$ \\
\hline 6 & Ilam & CAIla & 1250 & $87^{\circ} 90.32^{\prime} \mathrm{E}$ & $26^{\circ} 72.80^{\prime} \mathrm{N}$ \\
\hline 7 & Makwanpur (Hetauda) & CAMak & 650 & $85^{\circ} 0.32^{\prime} \mathrm{E}$ & $27^{\circ} 37.5^{\prime} \mathrm{N}$ \\
\hline 8 & Chitwan & CAChit & 200 & $84^{\circ} 3.22{ }^{\prime} \mathrm{E}$ & $27^{\circ} 60.71^{\prime} \mathrm{N}$ \\
\hline 9 & Pokhara(Kaski) & CAPok & 850 & $83^{\circ} 9.3^{\prime} \mathrm{E}$ & $28^{\circ} 16.99^{\prime} \mathrm{N}$ \\
\hline 10 & Dang & CADan & 650 & $82^{\circ} 4.13^{\prime} \mathrm{E}$ & $27^{\circ} 9.5^{\prime} \mathrm{N}$ \\
\hline 11 & Kathmandu (Kirtipur) & CAKir & 1350 & $85^{\circ} 17.32^{\prime} \mathrm{E}$ & $27^{\circ} 40.20^{\prime} \mathrm{N}$ \\
\hline 12 & Kathmandu (Matatirtha) & CAKMa & 1400 & $85^{\circ} 14.34^{\prime} \mathrm{E}$ & $27^{\circ} 40.54^{\prime} \mathrm{N}$ \\
\hline 13 & Dhangadi & CADhn & 130 & $80^{\circ} 2.25^{\prime} \mathrm{E}$ & $28^{\circ} 7.31 ' \mathrm{~N}$ \\
\hline 14 & Kanchanpur & CAKan & 120 & $80^{\circ} 2.25^{\prime} \mathrm{E}$ & $29^{\circ} 0.50^{\prime} \mathrm{N}$ \\
\hline 15 & Pyuthan & CAPyu & 1300 & $82^{\circ} 7.99^{\prime} \mathrm{E}$ & $28^{\circ} 2.28^{\prime} \mathrm{N}$ \\
\hline 16 & Dhankuta & CADhan & 1800 & $87^{\circ} 3.54^{\prime} \mathrm{E}$ & $26^{\circ} 77.70^{\prime} \mathrm{N}$ \\
\hline 17 & Surkhet & CASur & 675 & $81^{\circ} 5.99 ' \mathrm{E}$ & $28^{\circ} 6.25^{\prime} \mathrm{N}$ \\
\hline 18 & Banke & CABan & 150 & $81^{\circ} 3.99^{\prime} \mathrm{E}$ & $28^{\circ} 0.73^{\prime} \mathrm{N}$ \\
\hline 19 & Lamjung & CALam & 720 & $84^{\circ} 2.66^{\prime} \mathrm{E}$ & $28^{\circ} 14.57^{\prime} \mathrm{N}$ \\
\hline 20 & Dhampus(Kaski) & CADham & 1800 & $83^{\circ} 51.13^{\prime} \mathrm{E}$ & $28^{\circ} 18.012^{\prime} \mathrm{N}$ \\
\hline 21 & Bardiya & CABar & 150 & $81^{\circ} 36.90^{\prime} \mathrm{E}$ & $28^{\circ} 12.73^{\prime} \mathrm{N}$ \\
\hline
\end{tabular}


Solution : An extraction buffer consisting of $2 \%$ CTAB (w/v), Tris HCl pH 8.0 (0.5 M); EDTA pH 8.0 (0.5 M); $\mathrm{NaCl}$ (5.0 M), RNAase (4 mg/ml), Chloroform : lsoamylalcohol (24:1), Ethanol (70\%, 100\%) and TE buffer (Tris $\mathrm{HCl}, 10 \mathrm{mM}$, EDTA, $1 \mathrm{mM}$, pH 8.0) are the additional solutions required.

\section{DNA isolation}

Fresh leaves of C. asiatic were used for genomic DNA isolation for diversity study. Five samples from each population were used to extract the bulk DNA, which was isolated using Cetyl Trimethyl Ammonium Bromide (CTAB) (Sigma Aldrich, USA) protocol developed by Doyle and Doyle (1987) with slight modification . Young leaf tissue $(0.3 \mathrm{~g})$ was ground into a fine paste in liquid nitrogen in sterilized mortar and pestle and transferred to $600 \mu \mathrm{l}$ preheated extraction buffer [2\% CTAB; Cetyl Trimethyl Ammonium Bromide (CTAB)] at $65^{\circ} \mathrm{C}$. The slurry was incubated for $10 \mathrm{~min}$ at $65^{\circ} \mathrm{C}$ in water bath. Then $600 \mu \mathrm{l}$ of chloroform: isoamyl alcohol (24:1 v/v) (Qualigens Fine Chemicals) was added to this slurry and centrifuged at $14,500 \mathrm{rpm}$ for $26 \mathrm{sec}$ at room temperature. The supernatant was again treated with an equal volume of chloroform: isoamyl alcohol (24:1 $\mathrm{v} / \mathrm{v}$ ) and centrifuged at 14,500 rpm for $26 \mathrm{sec}$ at room temperature. The DNA was precipitated by adding ice cold absolute ethanol (100\%) (Sigma Aldrich) and centrifuged at $8000 \mathrm{rpm}$ for $1 \mathrm{~min}$ at room temperature. The pellet was washed with $70 \%$ ethanol (Sigma Aldrich) and dried in air for 5-10 min. The pellet was resuspended in 50 $\mu$ l Tris-EDTA(TE) buffer .Then $5 \mu \mathrm{l}$ $(4 \mathrm{mg} / \mathrm{ml})$ RNAase was added to each sample to digest the contaminants and stored at $-20^{\circ} \mathrm{C}$ for subsequent use.

\section{DNA quantification}

DNA isolates were checked for their quality and quantity using $0.8 \%$ agarose gel electrophoresis and compared the intensity of DNA with the known concentration of Lambda DNA marker. The nucleic acid concentration was calculated following Sambrook et al. (1989).

\section{RAPD reaction}

For the optimization of RAPD reaction ingredients, different combinations of concentrations were used to succeed amplification process (Table 2). The optimum RAPD-PCR reaction conditions were selected by varying several parameters viz. DNA concentration (25,50,75,100,150, $200 \mathrm{ng})$, primer concentration $(0.1,0.2,0.25,0.3,0.5,0.6,0.75 \mu \mathrm{M})$, master mix (PCR mix volume (3.2, 6.5, 7.5, 10.0, 12.5 \& 15 ìl) (Table 2). (Go Taq ${ }^{\circledR G}$ reen master mix contains reaction buffer $(\mathrm{pH}$ 8.5),400ìM dATP, 400ìM dGTP, 400ìM dCTP, 400ìM dTTP , 3mM $\mathrm{MgCl}_{2}$ Taq DNA polymerase and dye (Promega Corporation, USA, 2008).

Table 2. Optimization of RAPD-PCR reaction parameters for $C$. asiatica

\begin{tabular}{|c|c|c|}
\hline PCR Parameter & Tested range & $\begin{array}{l}\text { Optimum } \\
\text { conditions }\end{array}$ \\
\hline $\begin{array}{l}\text { DNA } \\
\text { concentration(ng) }\end{array}$ & $25,50,75,100,150,200$ & 100 \\
\hline $\begin{array}{l}\text { Primer } \\
\text { Concentration }(\mu \mathrm{M})\end{array}$ & $\begin{array}{l}\text { 0.1,0.2,0.25,0.3,0.5, } \\
0.6,0.75\end{array}$ & 0.5 \\
\hline $\begin{array}{l}\text { Master } \\
\text { vol. }(\mu \mathrm{l})\end{array} \quad \operatorname{mix}(2 \mathrm{X})$ & 3.2,6.5,7.5,10,12.5,15 & 12.5 \\
\hline $\begin{array}{l}\text { Initial denaturation } \\
\text { time interval (min) } \\
\text { at } 94^{\circ} \mathrm{C}\end{array}$ & $2,3,5$ & 3 \\
\hline $\begin{array}{l}\text { Annealing } \\
\text { Temp. }\left({ }^{\circ} \mathrm{C}\right)\end{array}$ & $27,30,32,35,37,40,50$ & 37 \\
\hline $\begin{array}{l}\text { Reaction } \\
\text { volume }(\mu \mathrm{l})\end{array}$ & $10.2,15,20,25,50$ & 25 \\
\hline Number of cycles & $25,30,35,40$ and 45 & 30 \\
\hline
\end{tabular}

DNA amplification was performed using a DNA Thermocycler (MJ Research Inc., USA). The optimum condition of Thermocycler was selected by varying initial denaturation duration (2, 3 \& 5 mins), number of denaturation cycles (25, 30, 35, 40 \& 45) and annealing temperature $\left(28,30,32,35,37,40 \& 50^{\circ} \mathrm{C}\right)$ (Table 2).

\section{Gel electrophoresis and PCR product documentation}

PCR products were analysed by electrophoresis on $1.5 \%(\mathrm{w} / \mathrm{v})$ agarose gels, in $1 \mathrm{X}$ TAE Buffer at $60 \mathrm{~V}$ $(2.5 \mathrm{~V} / \mathrm{cm})$ for $3 \mathrm{~h}$ and then stained with ethidium bromide (10 mg/ml). Gels with amplification fragments were visualized and photographed under UV light using Gel Doc 2000 (Bio-Rad, USA). The amplicon sizes were determined by comparison with the 100bp DNA ladder (Gene Ruler 100 bp ladder plus; Sigma Chemical Company, St. Louis, US). 


\section{Primer screening}

Using optimized reaction and cycling conditions for Centella asiatica, 21 decamer primers of arbitrary sequence (Kits $\mathrm{A}$ and $\mathrm{C}$ provided by Operon Technologies Inc., Alameda, CA) were screened across the 21 populations for PCR amplification, of which best primer producing crispy bands were selected for further experiments on genetic diversity assessment.

\section{Results and Discussion}

DNA extraction was improved by modifying some of the steps in the original CTAB - DNA isolation protocol (Doyle \& Doyle 1987). The fresh and young leaves were used. It resulted extracting, the high quality of genomic DNA with low-polysaccharide. Tannins, terpenes and resins considered as secondary metabolites are also difficult to separate from DNA (Ziegenhagen \& Scholz 1998). Certain polysaccharides are known to inhibit RAPD reactions. They distort the results in many analytical applications and therefore lead to wrong interpretations (Kotchoni et al. 2003). Polysaccharides like contaminants, which are undetectable by most criteria, can cause anomalous reassociation kinetics. Polysaccharide co-precipitation is avoided by adding a selective precipitant of nucleic acids, i.e. cetyltrimethyl ammonium bromide (CTAB) to keep polysaccharides in solution (Dellaporta et al. 1983). Long-term chloroform: isoamylalcohol treatment ensured removal of chlorophyll and other colouring substances such as pigments, dyes, etc. Many DNA isolation procedures also yield large amounts of RNA, especially $18 S$ and 25S rRNA (Doyle \& Doyle 1987). Large amounts of RNA in the sample can chelate $\mathrm{Mg}^{2+}$ and reduce the yield. RNase treatment degrade RNA into small ribonucleosides that do not contaminate the DNA preparation, and yield RNA-free pure DNA.

Additional precipitation steps removed large amounts of detergents, proteins and polysaccharides by centrifugation . DNA degradation and precipitations were avoided to some extent by carrying out all the steps at room temperature. We found these modified steps necessary to standardize and increase the quality and quantity of genomic DNA. DNA isolated by this method yielded strong and reliable amplification products showing its sustainability for RAPD-PCR using random decamer primers (Fig. 1\&2).

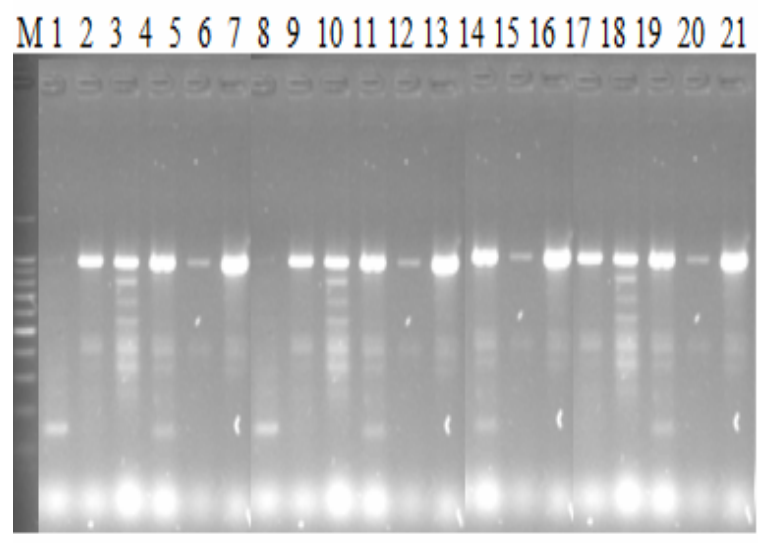

Fig. 1. RAPD-PCR of $C$. asiatica for the screening using OPC- 13 primer at $0.75 \mu \mathrm{M}$ concentration

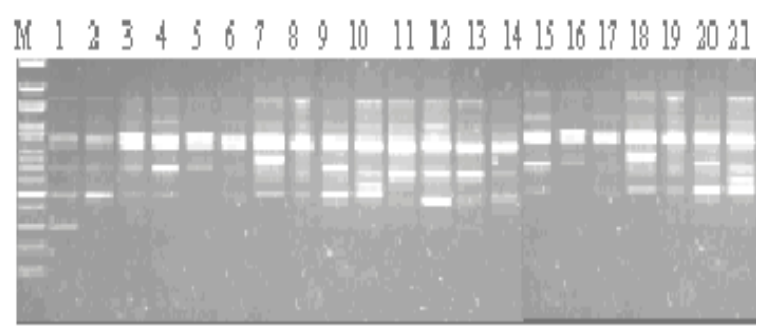

Fig. 2. RAPD-PCR of C. asiatica for the screening using OPC- 13 primer ( $0.5 \mu \mathrm{M}$ concentration) at present optimized condition

Almost all the tested parameters for RAPDs like the concentration of template DNA, primer, master mix (2X) and temperature and time intervals during denaturation, annealing and elongation were also optimized which also had an effect on amplification, banding patterns and reproducibility. The optimized conditions for RAPD protocol are given in Table 2. Among the tested conditions ,the reaction mixture carried in a volume of 12.5 ìl of Go Taq Green Master mix(2×) (Promega Corporation, USA), 1 ìl primer (0.5ìM), 7.5 ìl deionised water and 4 ìl DNA(100ng) proved to be more efficacious in yielding strong, more reliable amplification products as compared to other conditions. Higher or lower concentration of tested constituents beyond the optimized concentration resulting into lack of reproducibility (Weeden et al. 1992).

Besides this, among the tested condition of thermocycler, the best condition was considered for an initial denaturation of $3 \mathrm{~min}$ at $94^{\circ} \mathrm{C}$, followed by 30 
cycles of denaturation for $45 \mathrm{~s}$ at $94^{\circ} \mathrm{C}$, annealing for $1 \mathrm{~min}$ at $37^{\circ} \mathrm{C}$, and extension for $1 \mathrm{~min}$ at $72^{\circ} \mathrm{C}$ and final extension at $72^{\circ} \mathrm{C}$ for $7 \mathrm{~min}$.

Optimization of RAPD-PCR Conditions is essential for genetic diversity study. The present optimized protocol for DNA isolation and RAPD technique served as an efficient tool for further molecular studies of C. asiatica plant of Nepal.

\section{Acknowledgements}

The authors express their thanks to Biotechnology Unit, NARC and acknowledge Mrs Saileja Singh for her amiable assistance during laboratory work and also to Mrs Bina Dongol and other staffs of this unit, for their cordial help and laboratory support in carrying out this work.

\section{References}

Dellaporta, S.L., J. Wood and J.B. Hicks .1983. A plant DNA mini-preparation: version II. Plant Mol Biol Rep. I: $19-21$.

Devkota, A. and P.K. Jha. 2008. Biology and medicinal characteristics of Centella asiatica. In: Medicinal Plants in Nepal: An Anthology of Contemporary Research. (Eds. P.K. Jha, S.B. Karmacharya, M.K. Chettri, C.B. Thapa, B.B. Shrestha). Ecological Society (ECOS), Kathmandu, pp. 68-80.

Doyle, J.J. and J.L. Doyle.1987. A rapid DNA isolation procedure for small quantities of fresh leaf tissue. Phytochemical Bulletin 19: 11-15.

Jamil, S.S., Q. Nizami and M. Salam. 2007. Centell a asiatica (Linn.) Urban-A review. Natural Prouct Radiance 6: $158-170$.
Kotchoni S.O., E.W. Gachomo, E. Betiku, O.O. Shonukan.2003. A homemade kit for plasmid DNA minipreparation. African Journal of Biotechnology 2: 88-90.

Padmalatha K. and M.N.V. Prasad. 2006. Optimization of DNA isolation and PCR protocol for RAPD analysis of selected medicinal and aromatic plants of conservation concern from Peninsular India, African Journal of Biotechnology 5 (3) : 230-234.

Pikkart MJ and B Villeponteau.1993. Suppression of PCR amplification by high levels of RNA. Biotechniques 14: 24-25.

Press, J.R., K.K. Shrestha and D.A. Sutton. 2000. Annotated Checklist of the Flowering Plants of Nepal. The Natural History Museum, London and Central Department of Botany, Tribhuvan University, Kathmandu, Nepal.

Sajem, A.L. and K. Gosai. 2006. Traditional use of medicinal plants by the Jaintia tribes in North Cachar hills district of Assam, northeast India. Journal of Ethnobioliology and Ethnomedicine. 2:33-36.

Sambrook J, EF Fritsch and T Maniatis .1989. Molecular cloning: A laboratory manual. Cold Spring Harbor Laboratory Press, Cold Spring Harbor, New York, USA.

Shrestha, P.M. and S.S. Dhillion. 2003. Medicinal plant diversity and use in the highlands of Dolakha district, Nepal. Journal of Ethnopharmacology, 86:81-96.

Weeden NF, GM Timmerman, M Hemmat, BE Kneen and MA Lodhi. 1992. Inheritance and reliability of RAPD markers in the application of RAPD technology to plant breeding. In: Joint Plant Breeding Symposia Series (November 1, 1992), Minneapolis, MN. Crop Science Society of America, Madison, WI. pp.12-17.

Ziegenhagen B and F Scholz .1998. Methods for difficult plant species. In: Molecular Tools for screening Biodiversity 2.2. Plants and Animals, (Eds. Akarp P.G. Issac and D.S. Ingram.) Chapman and Hall, London. pp.32-35. 
Nepal Journal of Science and Technology 12 (2011) 69-74 